\title{
Expert views on TPACK for early literacy: Priorities for teacher education
}

\author{
Susan McKenney \\ University of Twente \\ Joke Voogt \\ University of Amsterdam \& Windesheim University of Applied Sciences
}

\begin{abstract}
Technology applications can make important contributions to improving learning outcomes in the domain of early literacy. However, to fully exploit the potential of educational technologies, teachers must have specific knowledge and skills. This study aimed to articulate the technological pedagogical content knowledge teachers need to make effective use of technology for early literacy. Through three rounds of expert consultation using a Delphi study approach, key priorities for the education of lower primary school teachers, especially those teaching kindergarten, were articulated. The results of the Delphi study show expert consensus on the importance of educating pre-service teachers about: electronic books and educative television; explicit goals and task-focused instructions using specific tools; how to shape technology-rich classroom interactions; and how to integrate computer activities in language teaching. Experts stress the importance of developing ageappropriate teaching skills and critical consideration of the value of technologies for specific learning goals. When this critical stance is lacking (e.g., using technology for entertainment, or substitution of existing activities), they recommend against technology use in kindergarten. These findings can help teacher education programs offer pre-service teachers adequate opportunities to develop the technological, pedagogical, and content knowledge needed for effectively using technology in the domain of early literacy.
\end{abstract}

\section{Introduction}

Software applications can make important contributions to improving learning outcomes in the domain of early literacy (McKenney \& Voogt, 2009). For example, research has shown that the use of electronic picture books, playing educative computer games, or the integration of specific technology-rich learning environments can positively influence the development of early literacy in kindergarten (Verhallen, Bus \& Jong, 2006). However, research shows that pre-service teachers do not feel well prepared to teach with technology (Tondeur, Pareja Roblin, van Braak, Fisser, \& Voogt, 2013). Enochsson and Rizza (2009) reviewed empirical research on how teacher education institutes are preparing pre-service teachers to use technology in their classrooms and found (1) a lack of competence and confidence in teaching with technology of pre-service teachers, (2) a lack of adequate technology resources both in the pre-service teacher training institutes as in schools where pre-service students conduct their internships, (3) a lack of role models and examples of appropriate use of technology important for forming teachers' professional identity, and (4) a lack of motivation, because technology is often not a compulsory part of the curriculum. Although other studies show how teachers can be prepared to teach with technology (see for instance the meta-ethnographic review of Tondeur et al., [2012]), Voogt, Fisser, Pareja Roblin, Tondeur, and Van Braak (2012) conclude, based on a review of research about technological pedagogical content knowledge (TPCK) (Koehler \& Mishra; 2009), that little research is available on what teachers need to know when they want to teach with technology in a specific subject matter domain. Therefore, this study was undertaken to articulate the knowledge and skills that primary school (and especially kindergarten) teachers need for working effectively with technology-rich learning environments for early literacy, and hence what pre-service teachers need to be taught in initial teacher education.

\section{Theoretical framework}

When it comes to technology-enhanced learning, the technological pedagogical content knowledge (TPACK) model of Koehler and Mishra (2009) provides a useful conceptual framework for articulating the kinds of knowledge teachers need to teach with technology in a specific subject domain. This model assumes that teachers need not only distinct knowledge of technologies, pedagogies, and subject matter, but that these knowledge domains must also be integrated, that is technological content knowledge 
(TCK), pedagogical content knowledge (PCK), or technological pedagogical content knowledge (TPCK). Both the discrete and integrated types of knowledge inform teacher decisions when selecting and using curricular resources (Voogt et al., 2012). This study focuses on the knowledge pre-service teachers need in particular.

\section{Hardware/software for early literacy: TCK}

Several review studies about beneficial technology applications for early literacy have implications for the knowledge teachers need TCK, if they are to use these tools for disciplinary learning. Lankshear and Knoebel (2003) lament the dearth of research in the 0-8 year old age range, and indicate that the corpus of studies found was:

[S]wamped by an emphasis on developing a generic capacity to encode and decode alphabetic print rather than to promote competence as "insiders" of practices and discourse communities that extend beyond conventional classroom reading and writing. Most of the studies involve "reading/receiving" text-mediated meanings rather than “writing/generating” meanings. (Lankshear \& Knoebel, 2003; p. 77)

A decade later, Belo, McKenney, Voogt, and Bradley (2016) found that the following types of software applications can be effective in fostering children's early literacy development; electronic storybooks, computer-based programs that specialise in phonics and vocabulary training, software applications that enable children to read and write, software tutorials, and educational television programs with a narrative format. Other studies have shown that technologies can contribute to literacy development, for example as a beneficial by-product of knowledge building (Pelletier, Reeves, \& Halewood, 2006).

\section{Features of hardware/software: TCK and PCK}

While many potentially valuable tools are available today, all teachers need to be aware of research evidence about the affordances of specific technologies and their potential applications for children's early literacy development (cf. Robinson, Johanson, Schneider \& Hutinger, 2006). This includes awareness of evidence pertaining to both the substance and the interface of software, as it determines the way the software impacts the way content is being taught. Knowledge about the features of hardware and software from the perspective of subject matter content (TCK) and from the perspective of pedagogy (PCK) is therefore an important aspect of the teachers' knowledge base for teaching with technology. For example, software that is intended to promote active language use and understanding of related linguistic concepts should include pro-social, language-eliciting opportunities, for example by supporting the creation and use of language or linguistic products in authentic ways (McKenney \& Voogt, 2009; Van Scoter, 2008). At the same time, the interface of educational software for use by young children should be attuned to the ergonomic needs of the age group, such as large buttons, oversized cursors, and minimal need for dragging icons (Segers \& Verhoeven, 2002). In addition, teachers need to be aware of potentially counterproductive features such as cued animations or sound effects that can provide inconsiderate distractions and have adverse effects on pupil concentration (Takacs, Swart, \& Bus, 2015). Related to both content and interface, technologies used with young children should be developmentally appropriate (for recommended practices pertaining to technology and children aged 3-8 years, see National Association for Education of Young Children, 1996). Knowledge of salient features of hardware and software stands to increase teachers' sense of self-efficacy concerning technology integration. For pre-service teachers, vicarious learning experiences can positively influence self-efficacy regarding technology integration, especially when coupled with explicit goal setting (Wang, Ertmer, \& Newby, 2004).

\section{Using hardware/software: TPCK}

Effective integration of technology requires knowledge that enables teachers to identify and use technological affordances to support student learning (Webb \& Cox, 2004). TPCK is required to make use of technological affordances for teaching specific content in ways that are effective and pedagogically appropriate (Koehler \& Mishra, 2009). It requires teachers to know how effective use can be made of the affordances of technology for specific content (e.g., Wright \& Wilson, 2005). In addition all teachers need to be able to recognise how technology can supplement or expand existing curricular lines (Cassidy 
\& Smith, 2003). In addition to curricular compatibility, technology integration also requires that teachers take into account individual learner characteristics (e.g., difficulty levels, self-regulation, etc.) when selecting technologies (Hartley \& Benedixen, 2001). Finally, because the context in which technologies are used is also salient to successful integration this process requires that all teachers consider specific characteristics of the implementation setting (Koh, Chai, \& Tay, 2014).

\section{Methods}

\section{Purpose}

The goal of the present study was to identify and articulate the knowledge base pre-service teachers need in order to effectively use technology to help foster early literacy. This information is intended for use by teacher education programs that include a specific focus on young children in general and early literacy in particular. In accordance with the theoretical framing presented earlier, the study sought to identify and describe:

- $\quad$ specific software applications and/or hardware with added value for developing early literacy,

- features of effective technology with added value for developing early literacy, and

- $\quad$ guidelines for effective uses of technology for developing early literacy.

Given the availability of software in local languages, the findings related to specific applications are likely to be especially relevant to Dutch-speaking teacher education programs. In contrast, the findings related to technology features and guidelines for use are not language dependent, and are therefore useful to a wide range of teacher education programs.

\section{Context}

The study was carried out with Dutch-speaking respondents from Belgium and the Netherlands. Early years education is a priority in both countries. While parents are viewed as most responsible for raising their children, the state also contributes by offering public schooling from early on. Within the education system, and as part of the elementary school, pre-school is open to all children, starting at age two and a half in Belgium, and at age four in the Netherlands. In both countries, compulsory school age begins at six. In Belgium, the pre-school teacher program is distinct from the primary school teacher education program, and focuses specifically on working with children of ages two and a half to six. In the Netherlands, all primary school teachers are educated through one core teacher education program, and teaching students choose to specialise in lower grades (ages 4-8 years) or upper grades (ages 8-12 years). In both countries, these teachers hold bachelor degrees (or higher). This study focused on the knowledge that pre-service teachers need for working with children aged 4-6 years, referred to here as (junior and senior) kindergarten.

\section{Delphi technique}

The literature review that informed our study (Belo et al., 2016) showed that research about design features of technology applications for early literacy and effective use is scarce. This particular kind of information can be obtained from experts with professional experiences in the field. For this reason, we decided to use the Delphi technique, because it aims to achieve consensus in the presence of insufficient or contradictory information. The Delphi technique features structured, successive rounds of communication in which a facilitator provides specific, anonymous inputs for expert comment. It originated decades ago at the Rand Corporation for futurecasting, has been widely used in healthcare research since then. It has been used to research higher education curriculum priorities for at least 30 years (Haussler, Frey, Hoffman, Rost, \& Spada, 1980; Smith \& Simpson, 1995). The design of the present study was informed by guidelines, critique and examples of Delphi studies in higher education as well as other fields (e.g., Hasson, Keeney, \& McKenna, 2000; Osborne, Collins, Ratcliffe, Millar, \& Duschl, 2003; Shaikh \& Khoja, 2014; Volman, 2005). 


\section{Respondents}

As is characteristic of the Delphi technique, the present study involved a fixed group of experts representing multiple facets of expertise related to the focus of the study. To select the experts we started by composing an inventory of Dutch and Belgian experts in technology, language teaching, and early literacy through examining websites of teacher education institutes, online platforms (such as technology expertise and language teaching networks), and a research database on the use of technology in education. Although we initially aimed to include persons with expertise in all three domains, our search showed that such experts were difficult to find. Therefore we decided to obtain a balance between experts of all three domains. Experts on our final list $(n=24)$ were invited by email to participate in the study, which would take place in three rounds. Of these, 14 participants agreed, and participated in the first round. There was some attrition in subsequent rounds, for example due to maternity leave or change of employment, yielding 12 participants in the second round and 8 in the third round. We asked the participants to describe their formal work title and rank their own expertise with regard to each of the TPACK area separately (technology in education, early literacy, primary school pedagogy) and in relation to the integrated TPACK domains (use of technology for the language learning of young children). As shown in Table 1, the expertise distributed across the respondents who agreed to participate covered all relevant areas. The research reported in this paper was conducted with consenting adults and adheres to the ethical standards of the participating universities.

Table 1

Expertise distribution within the respondent group based on respondent self-reporting

\begin{tabular}{|l|c|c|c|c|c|}
\hline \multicolumn{1}{|c|}{ Item } & \multicolumn{2}{c|}{ How much knowledge and expertise? } \\
\hline & None & A little & Average & Much & $\begin{array}{c}\text { Very } \\
\text { much }\end{array}$ \\
\hline ICT and education & & & & & \\
\hline ICT and education in general & 0 & 3 & 4 & 5 & 2 \\
\hline Use of ICT to support general learning processes & 1 & 3 & 3 & 6 & 1 \\
\hline Use of ICT to support teaching in primary school & 0 & 4 & 3 & 5 & 2 \\
\hline Effective integration of ICT in primary schooling & 1 & 4 & 3 & 4 & 2 \\
\hline Use of ICT to support the learning of kindergarteners & 2 & 3 & 3 & 4 & 2 \\
\hline $\begin{array}{l}\text { Use of ICT to support the teaching of kindergarten } \\
\text { teachers }\end{array}$ & 2 & 3 & 4 & 3 & 2 \\
\hline Effective integration of ICT in kindergarten & 2 & 3 & 4 & 4 & 1 \\
\hline Language teaching and early literacy & & & & & \\
\hline $\begin{array}{l}\text { Teaching and learning activities that contribute to } \\
\text { developing early literacy in general }\end{array}$ & 0 & 2 & 2 & 7 & 2 \\
\hline Activities related to book orientation & 0 & 4 & 0 & 8 & 2 \\
\hline Activities related to story understanding & 0 & 4 & 0 & 8 & 2 \\
\hline Activities related to the functions of written language & 1 & 3 & 1 & 7 & 2 \\
\hline $\begin{array}{l}\text { Activities related to the relationship between spoken } \\
\text { and written language }\end{array}$ & 0 & 4 & 1 & 7 & 2 \\
\hline Activities related to linguistic consciousness & 0 & 3 & 2 & 7 & 2 \\
\hline Activities related to the alphabetic principle & 0 & 3 & 3 & 5 & 3 \\
\hline Activities related to functional reading and writing & 0 & 4 & 2 & 5 & 3 \\
\hline $\begin{array}{l}\text { Activities related to initial technical reading and } \\
\text { writing }\end{array}$ & 1 & 4 & 2 & 3 & 4 \\
\hline $\begin{array}{l}\text { Activities related to subsequent technical reading and } \\
\text { writing }\end{array}$ & 1 & 4 & 3 & 1 & 4 \\
\hline $\begin{array}{l}\text { Activities related to reading and writing } \\
\text { comprehension }\end{array}$ & 1 & 4 & 3 & 2 & 4 \\
\hline
\end{tabular}




\begin{tabular}{|l|c|c|c|c|c|}
\hline \multicolumn{1}{|c|}{ Item } & \multicolumn{5}{|c|}{ How much knowledge and expertise? } \\
\hline & None & A little & Average & Much & $\begin{array}{c}\text { Very } \\
\text { much }\end{array}$ \\
\hline Language teaching & & & & & \\
\hline $\begin{array}{l}\text { Teaching and learning activities that contribute to the } \\
\text { development of verbal communication in general }\end{array}$ & 1 & 2 & 2 & 8 & 0 \\
\hline Activities related to participating in conversation & 1 & 2 & 1 & 8 & 2 \\
\hline Activities related to interactive learning & 1 & 2 & 1 & 9 & 1 \\
\hline Activities related to language use & 1 & 1 & 4 & 6 & 2 \\
\hline Activities related to vocabulary & 1 & 1 & 3 & 5 & 4 \\
\hline Activities related to listening comprehension & 2 & 3 & 2 & 7 & 0 \\
\hline Activities related to speaking and presenting & 1 & 2 & 2 & 8 & 1 \\
\hline Activities related to reflecting on communication & 3 & 1 & 4 & 5 & 1 \\
\hline Activities related to reflecting on language & 3 & 2 & 2 & 6 & 1 \\
\hline ICT and early literacy & & & & & \\
\hline ICT applications with added value for EL & 4 & 4 & 3 & 3 & 0 \\
\hline ICT applications with added value for VC & 3 & 4 & 1 & 5 & 1 \\
\hline $\begin{array}{l}\text { ICT applications with added value for testing and } \\
\text { monitoring }\end{array}$ & 2 & 6 & 3 & 2 & 1 \\
\hline $\begin{array}{l}\text { ICT applications with added value for children with } \\
\text { problems or language development delays }\end{array}$ & 2 & 5 & 2 & 4 & 1 \\
\hline $\begin{array}{l}\text { Language teaching principles regarding effective ICT } \\
\text { use in relation to EL and VC }\end{array}$ & 2 & 5 & 3 & 3 & 1 \\
\hline $\begin{array}{l}\text { Pedagogical principles regarding effective ICT use in } \\
\text { relation to EL and VC }\end{array}$ & 2 & 6 & 3 & 2 & 1 \\
\hline $\begin{array}{l}\text { Organizational principles regarding effective ICT use I } \\
\text { relation to EL and VC }\end{array}$ & 2 & 2 & 3 & 2 \\
\hline
\end{tabular}

Note. ICT = information and communication technologies; EL = early literacy; VC = verbal communication. Items in italics are directly linked to the Dutch national interim targets for early literacy.

\section{Procedures}

The Delphi technique is an iterative, multi-stage process designed to transform opinion into group consensus (Hasson et al., 2000). In accordance with recommended practice (Hsu \& Sandford, 2007), this study was structured into three rounds of collecting and classifying opinions (see Table 2). The careful analysis of opinions in the first and second rounds shaped the questions asked in the second and third rounds, respectively. With each round, the focus grew increasingly narrow.

Table 2

Overview of focus and data sources in each round

\begin{tabular}{|l|l|l|}
\hline Round 1 & $\begin{array}{l}\text { Expert opinions about the knowledge pre-service teachers } \\
\text { need to make effective use of technologies for early literacy. } \\
\text { No prior information given. }\end{array}$ & Open-ended questionnaire \\
\hline Round 2 & $\begin{array}{l}\text { Expert ranking of priorities for pre-service teacher } \\
\text { curriculum. List of priorities was based on synthesis of } \\
\text { previous round responses and standpoints from literature. }\end{array}$ & $\begin{array}{l}\text { Closed questionnaire } \\
\text { Telephone interview }\end{array}$ \\
\hline Round 3 & $\begin{array}{l}\text { Expert ranking of necessity for pre-service teacher } \\
\text { curriculum. List of priorities stayed the same, but reasons } \\
\text { given by experts (during telephone interviews) were } \\
\text { described for each item. }\end{array}$ & Closed questionnaire \\
\hline
\end{tabular}

During the first round, expert opinion was solicited through an open-ended questionnaire about the knowledge pre-service teachers need to make effective use of technologies for early literacy. During the second round, respondents were presented with a synthesis of their own opinions, as well as standpoints from a literature review, and asked to rank each item for importance in the pre-service teacher curriculum. In addition to administering the questionnaires, telephone interviews were conducted to gather participant 
reasoning behind each response. During the third round, the same items were presented to the experts, but this time participants were also asked their reasons for not prioritising each item. In light of potentially new considerations about each item, respondents were asked to rank the necessity for each item in the pre-service teacher education curriculum, and to indicate why they gave it this classification using one of the reasons given or entering a new one. As recommended elsewhere (So \& Bonk, 2010), data collection and analysis were coordinated by a central working group, and participant identities were kept anonymous throughout the course of the study to eliminate potential cross-respondent influences based on reputation, hierarchy, or personality.

\section{Instruments and data analysis}

\section{Round 1}

The questionnaire used to solicit expert opinion in the first round contained three open-ended items on what student teachers need to know in order to make effective use of technology for early literacy. The items were kept quite broad to invite a wide range of responses: (1) TPCK: Which knowledge and skills do pre-service teachers need to make effective use of technologies and integrate them in their early literacy teaching? (2) TCK and PCK: Which content related principles are important for effective use of technology in relation to developing early literacy in young children? and (3) TCK: Which organisational and pedagogical principles with regard to technology use do pre-service teachers need to know if they wish to use technology effectively for the language learning of young children?

All responses were captured through an online questionnaire system. The qualitative responses were first coded inductively, to explore emerging themes. Thereafter, they were coded deductively, for relevance to the main research themes (applications and/or hardware, features, or guidelines).

\section{Round 2}

The second round featured a questionnaire with closed items and follow-up interviews. The closed items were based on a synthesis of the expert opinions obtained in round one, as well as key standpoints from literature (Belo, McKenney, Voogt, \& Bradley, 2016; McKenney \& Voogt, 2009). The closed items were clustered into three sets, each one relating to a main question: (1) TCK: For pre-service teachers, knowledge about which software applications and/or hardware with added value for developing early literacy is essential? (2) TCK and PCK: For pre-service teachers, knowledge about which effective characteristics of technology with added value for developing early literacy is essential? and (3) TPCK: For pre-service teachers, knowledge about which effective use of technology is essential for developing early literacy? Within each main question, specific items were given. For each item, respondents ranked its importance for the pre-service curriculum as being unimportant, important, or essential. For example, relating to the first main question, "interactive whiteboards" was an item in the hardware section, and "electronic books" was an item in the software section. After the questionnaires were completed, telephone interviews (of about 60 minutes each) were conducted with each respondent to obtain their reasoning behind each answer.

The closed item responses were analysed quantitatively, by calculating descriptive statistics. The interviews were transcribed and analysed qualitatively. Here too, responses were coded inductively, to explore emerging themes. As the instrument in the second round already incorporated the areas of applications and/or hardware, features, or guidelines, deductive coding was not deemed necessary.

\section{Round 3}

The questionnaire used in the third round contained the same basic structure as in the previous round. This time, however, respondents were also presented with reasons to include/exclude each item, based on the interviews in the second round. Given these potentially new perspectives, respondents again ranked each item. Based on feedback from the previous interviews, new terms were used to rank the importance of each item for inclusion in the pre-service teacher curriculum: must be included; nice if possible; not necessary. Respondents also indicated which of the reasons provided (or "other, namely ...") was most influential in choosing their ranking.

As in the previous round, the closed item responses were analysed by calculating descriptive statistics. Additionally, consensus for each item was calculated using the median threshold for consensus as reported by Diamond et al. (2014): 75\% agreement. Thus, when 75\% or more respondents gave the same 
response (e.g. “must be included”) consensus was obtained. Additionally, frequency counts were calculated for the reasons given by respondents. This helped understand not only what experts agreed on, but why.

\section{Results}

\section{Round 1}

As described previously, the items in the first questionnaire were kept quite broad to invite a wide range of responses. Through the 2-step process (first inductive, then deductive coding), responses were mapped to the main research themes: applications and/or hardware, features, or guidelines.

\section{Applications and/or hardware}

The experts gave examples of applications and hardware that potentially held added value for kindergarteners in general, and for early literacy in particular. The most frequently mentioned application was digital storybooks, including specific brands (e.g., Fundels) and forms thereof (e.g., Bereslim, and others that are directly linked to vocabulary software). Vocabulary software was also mentioned, both in general teams and through specific examples (e.g., Ambrasoft). For speaking and listening also, general and specific software were recommended (e.g., 2Simple Infant Video Toolbox), especially in combination with verbal skills development. Reading software (e.g., Leesladder) and those accompanying the kindergarten language curriculum being used (e.g., Schatkist) were suggested as well. Simple word processors were mentioned, and one respondent noted that applications could be developed for children to create and manage their own portfolios. Finally, several general applications (e.g., Skype, OPStap) and websites (e.g., IBM KidSmart) were noted for their potential contribution to kindergarten learning.

Tablets were the most frequently mentioned form of hardware. According to one respondent, "Since tablets have arrived, it has become clear that there are huge possibilities for their use in kindergarten learning." Some respondents indicated that desktop computer use was less appropriate for the kindergarten classroom because they are bulky and inconvenient. The experts indicated that interactive white boards were useful and some specifically mentioned the value of using these in combination with storytelling and reading aloud to children. In addition, printers and multi-touch tables were mentioned.

\section{Features}

The experts indicated several features of effective technology with added value for developing early literacy. Related to the content, they mentioned the importance of software that included lots of: interactivity and feedback (in accordance with edutainment); repetition (e.g., of words); practice opportunities (e.g., exercises); challenge; and visualisations (e.g., images). For example, it was noted that technology can be very helpful to practice specific skills related to auditory analysis and synthesis, such as letter knowledge, vocabulary development, and listening comprehension. Further, many of the experts pointed to the importance of technological features that help children express themselves. This was considered to be because, "literacy includes verbal communication and is not only about learning to read." Similarly, one respondent said, "children can reconstruct stories with the aid of ready-made images, pictures, or photos they have made. With the aid of technology, some children tell more than when they just put drawings or prints into sequence.” As another respondent explained, "chronological sequencing from left to right, ensures that children gain experience with writing direction.”

Concerning the interface, many said the technology should be easy to use, attractive, and multimodal (coordinated visual and audio support). While one expert lamented the fact that most applications are not available in Dutch, others suggested that some are sufficiently intuitive that children can make good use of software developed for adult/generic use, such as those for taking photos or recording sounds and movies. One pointed out that, while information-processing skills need to be developed in kindergarten, "one does not have to be literate to be able process information through images and sound." Another went as far as to say, "children's applications should not be too simplified.”

The experts also commented on how technologies should align with the contexts in which they are used. Specifically, they said that technologies should be flexible to use, with "various pedagogical possibilities." They also suggested that technology should be well-aligned with: the learning and development processes of young children, principles of developmentally appropriate practices, and 
curricula used in schools. Finally, the respondents discussed several important features of the settings in which technology is used. These included: financial policies regarding technology and its use, facilitation and access to technology, role of school leaders, vision and culture for technology use, and cooperation with third parties. In addition, many experts stressed the importance of ongoing professional development in the area of technology use.

\section{Guidelines}

The experts offered guidelines concerning effective uses of technology for developing early literacy that related to teacher knowledge, skills, and attitudes. They mentioned that pre-service teachers need knowledge of the software and hardware available for early literacy, as well as features of the software that can yield added value for kindergarten learning. Respondents also discussed the importance of knowledge about the learning and development of young children and specific principles concerning developmentally appropriate practices. These included learning that is: interactive, authentic, meaningful, and adaptive; accompanied by modeling and feedback; and rich with opportunities to develop metacognitive skills such as self-regulation. Related specifically to the domain of early literacy, they stressed that teachers should have knowledge of: how early literacy develops, how to support that development, and the affordances or limitations of learning resources for early literacy. They named these aspects in general, as well as with regard to early literacy (e.g., how young children use technology, and the sequence and frequency with which technology-rich learning activities should be undertaken to foster learning). Finally, they mentioned that pre-service teachers need to develop knowledge of learner characteristics (e.g., concentration, independence, learning styles, language ability, motor skills, and ability to cooperate) in order to in order to evaluate and select appropriate activities and decide how to use them.

The expert group articulated three main skill sets pre-service teachers need to be able to use technology well for early literacy development. They stressed the importance of being able to attune teaching and learning to learner needs, and noted that this requires pedagogical skills, organisation/classroom management skills, and communicative skills. A second skill set was technical; being able to operate various specific technologies. The third skill set pertained to the integration of technology when working to develop early literacy. They mentioned the importance of pre-service teachers' repertoire for developing early literacy, including using technology for: active, as opposed to passive language use; preand re-teaching; working with various groupings (individual, pairs, small group, and child-led presentations).

Respondents also indicated several attitudes and beliefs that pre-service teachers need to be able to make effective use of technology for early literacy. They indicated that teachers need positive attitudes toward technology, and to be able to see the value of technology for education. Further, they stressed that preservice teachers need an inquisitive stance; to dare to experiment with technology. Finally, the experts suggested that it is important for all teachers to be critical, looking for empirical evidence concerning the effects of technology use, through systematic evaluation in their own classrooms and elsewhere.

\section{Round 2}

Based on the results of the first round a closed questionnaire was developed for the second round. The questionnaire used in the second and the third rounds contained the same items. The main difference was that, in the second round, respondent answers and explanations for each answer were captured by telephone interviews. Because it is crucial to understanding expert opinion, this section discusses the respondent reasoning, stimulated by the questionnaire and captured through the interviews. Respondent rankings of specific items are given in the subsequent section.

Table 3 presents a paraphrased overview of the reasons given during the telephone interviews for including and excluding items in relation to each main section of the questionnaire. As it shows, the mostfrequently cited reason $(n=12)$ for including specific applications and hardware (RQ1) was that teachers must be aware of technology that is easily and/or broadly accessible in education today, explaining, for example that "it is essential to know about this [electronic learning environments]. [I]t is increasingly common for schools to use these." Mentioned quite often $(n=10)$ in relation to hardware and software and more than any other reason in total $(n=56)$, the experts mentioned 29 times that teachers must be able to know (in alignment with the curriculum) and/or critically determine that technology, in a given 
case, is an adequate pedagogical tool to achieve the intended learning goal. As one expert said concerning features of software for early literacy (RQ2), "What is important to me is that the teacher knows that the combination of images and spoken words is more effective ... teachers need to identify the difference between good software and poor software ... to be able to make decisions." The most frequently mentioned $(n=15)$ reason for including items related to guidelines for effective use (RQ3) was that teachers must be able to select and use it in accordance with the principle of functionality and pedagogical opportunities. For example, in response to an item about children reconstructing stories with the aid of digital images, one respondents said, "I think it is really important that they [children] make things themselves. That is so motivating! And because they are motivated, they make huge leaps. [T]his is something you [a teacher] really can do, whereby it is possible to incorporate lots of input from the children." Reasons given for not prioritising certain items pertained to irrelevance (e.g., not specifically relevant to early literacy or to technology use), or to overly specific information about interface design.

Table 3

Reasons given for items related to each main question

\begin{tabular}{|c|c|c|c|c|}
\hline & RQ1 & RQ2 & RQ3 & Total \\
\hline \# Items in each section of the questionnaire & 19 & 39 & 28 & 86 \\
\hline \multicolumn{5}{|l|}{ Reasons for including an item } \\
\hline $\begin{array}{l}\text { aTeachers must be able to know (in alignment with the curriculum) } \\
\text { and/or critically determine that ICT in this specific case is an } \\
\text { adequate pedagogical tool to achieve the intended learning goal }\end{array}$ & 10 & 29 & 15 & 54 \\
\hline $\begin{array}{l}\text { 'Teachers must be able to select and use ICT in accordance with the } \\
\text { principle of functionality and pedagogical opportunities }\end{array}$ & 2 & 3 & 15 & 20 \\
\hline 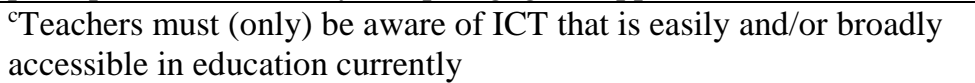 & 12 & 1 & 4 & 17 \\
\hline${ }^{\mathrm{d}}$ Teachers must become skilled in working with ICT & 2 & 8 & 7 & 17 \\
\hline $\begin{array}{l}\text { eTeachers must be able to use ICT as an effective tool for } \\
\text { differentiation in education (with regard to level, social, cultural and } \\
\text { linguistic background, etc.) }\end{array}$ & 4 & 8 & 12 & 16 \\
\hline $\begin{array}{l}{ }^{\text {f}} \text { Teachers must be able to use ICT as an effective tool to test and } \\
\text { monitor the learning development of their children }\end{array}$ & 2 & 2 & 4 & 8 \\
\hline $\begin{array}{l}\text { gTeachers must know something about ICT, because this (in the } \\
\text { future) is an important supplement for what takes place in regular } \\
\text { education, currently }\end{array}$ & 7 & 1 & 0 & 8 \\
\hline $\begin{array}{l}\text { hTeachers must be able to select and use ICT in accordance with the } \\
\text { principle of 'evidence-based' practice }\end{array}$ & 3 & 2 & 0 & 5 \\
\hline $\begin{array}{l}\text { iTeachers must be able to use ICT in their teaching, because they } \\
\text { work with children who are growing up in a digital era }\end{array}$ & 3 & 0 & 1 & 4 \\
\hline $\begin{array}{l}\text { jTeachers must be able to use ICT in accordance with their vision on } \\
\text { teaching and learning }\end{array}$ & 0 & 1 & 3 & 4 \\
\hline $\begin{array}{l}\text { kTeachers must be able to use ICT as a tool to support parental } \\
\text { involvement }\end{array}$ & 1 & 0 & 0 & 1 \\
\hline \multicolumn{5}{|l|}{ Reasons for excluding an item } \\
\hline $\begin{array}{l}{ }^{\text {l}} \text { Teachers do not need to know this, because it is not a specific aspect } \\
\text { of early literacy and/or is not in service of early literacy }\end{array}$ & 3 & 12 & 11 & 26 \\
\hline $\begin{array}{l}\text { mTeachers do not need to know this, because it is not specifically } \\
\text { related to ICT }\end{array}$ & 0 & 5 & 12 & 17 \\
\hline $\begin{array}{l}\text { nTeachers do not need to know this, because it is too specifically } \\
\text { related to the (interface) design of software applications }\end{array}$ & 0 & 13 & 0 & 13 \\
\hline $\begin{array}{l}{ }^{0} \text { Teachers do not need to know this, because it is not specific to } \\
\text { kindergarten learning }\end{array}$ & 2 & 0 & 4 & 6 \\
\hline pTeachers have this knowledge and/or skill already & 4 & 2 & 0 & 6 \\
\hline
\end{tabular}

Note. The superscript letters are used in the text below to indicate specific items. 


\section{Round 3}

As previously noted, the questionnaire used in the third round contained the same items as in the second round. First, respondents were asked to indicate the importance of each item for inclusion in the preservice teacher curriculum (not necessary, nice if possible, and must be included). Second, they were asked to indicate why they gave specific rankings, by selecting from pre-determined reasons (based on the findings from the second round) or writing in their own.

Consensus was established for six items ranked as must be included. The experts deemed knowledge about the following to be essential in the pre-service teacher curriculum: electronic books and educative television programs (applications/hardware); software goals and use (features); and forms of interaction as well as integration of computer activities in teaching (guidelines). Consensus was not found for any items in the category nice if possible. For items ranked not necessary, consensus was found for six items. The experts recommended excluding educative games, interactive white boards, and printers (applications/hardware). They also recommended excluding activities involving typing, worksheets, and vocabulary flashcards (guidelines). Table 4 shows an overview of the 12 rankings from the third round, for which consensus (threshold: 75\%) was found, in relation to each main question. Thereafter, the reasons given for each item are discussed.

Table 4

Expert consensus on items to include and exclude from teacher education curriculum

\begin{tabular}{|c|c|}
\hline RQ & Items with $75 \%$ agreement or more \\
\hline & Items ranked: Must be included \\
\hline \multirow[b]{2}{*}{$\begin{array}{l}\text { Applications/ } \\
\text { hardware }\end{array}$} & Electronic books (e.g., living books, digital story books, etc.) \\
\hline & $\begin{array}{l}\text { Educative television programs, commercial or non-profit (e.g., Sesame Street, } \\
\text { SchoolTV) }\end{array}$ \\
\hline \multirow{2}{*}{ Features } & $\begin{array}{l}\text { Instructions for working with software (clear, succinct, supported with images, task- } \\
\text { focused) }\end{array}$ \\
\hline & $\begin{array}{l}\text { Goals (explicit, instructions for use, added-value clarified, evidence-based, theory- } \\
\text { informed) }\end{array}$ \\
\hline \multirow{5}{*}{ Guidelines } & Forms of interaction (small circle, pairs, teacher-child, small groups) \\
\hline & $\begin{array}{l}\text { Integration of computer activities in language teaching (curriculum alignment, } \\
\text { thematic alignment, use for interaction and meaning-making, vocabulary enriching, } \\
\text { presentations) }\end{array}$ \\
\hline & Items ranked: Nice if possible \\
\hline & None with $75 \%$ agreement or more \\
\hline & Items ranked: Not necessary \\
\hline \multirow{3}{*}{ Applications } & Educative games, commercial or non-profit \\
\hline & Interactive white boards \\
\hline & Printers \\
\hline \multirow{3}{*}{ Guidelines } & Typing letters to create words, supported with images \\
\hline & Worksheets that offer opportunities to practice distinguishing sounds in speech \\
\hline & Making and using vocabulary flashcards with words and images \\
\hline
\end{tabular}

Reasons for including consensus items

Consistent with the findings from the second round, the most frequently cited reason for including any item was: ${ }^{a}$ Teachers must be able to know (in alignment with the curriculum) and/or critically determine that technology in this specific case is an adequate pedagogical tool to achieve the intended learning goal. With regard to electronic books, another reason given just as frequently was (also the second most common answer overall in the second round): ${ }^{\text {b}}$ Teachers must be able to select and use technology in accordance with the principle of functionality and pedagogical opportunities. Not only did the experts agree that educative television programs should be addressed in the teacher education curriculum, there was also consensus on why, as 75\% indicated that: ${ }^{9}$ Teachers must know something about technology, because this (in the future) is an important supplement for what takes place in regular education, currently. 
One set of features the experts agreed should be included in the teacher education programs related to instructions for working with software. Most respondents said they ranked this as important because either ${ }^{d}$ teachers must become skilled in working with ICT, or to help determine if a particular package ${ }^{\text {as }}$ an adequate pedagogical tool to achieve the intended learning goal, although a few pointed out that understanding these are important for all resources, not just technological ones. Most of the experts said that pre-service teachers need to learn about the goals of specific software to help determine if it is an aadequate pedagogical tool, though several also mentioned the need for understanding affordances for edifferentiation.

Even though some of the experts pointed out that knowledge of interaction forms (using resources with small circle, pairs, teacher-child, small groups) was ${ }^{\mathrm{m}}$ not specific to technology-enhanced learning, there was consensus that this was an important type of guideline for technology use, because it contributes to helping teachers select and use ICT in baccordance with functionality and pedagogical opportunities, or (related to the curriculum) to learning goals. This last reason was also given most frequently for why it is important to attend to integration of computer activities in language teaching in the pre-service curriculum, with knowledge of edifferentiation possibilities also being mentioned.

\section{Reasons for excluding consensus items}

The most frequently-cited reason for excluding educative games, interactive white boards, and printers from the pre-service curriculum was that ${ }^{\mathrm{P}}$ pre-service teachers already have the knowledge and skills needed to use these. Interestingly, half of the respondents indicated that it was not necessary to teach preservice teachers guidelines related to using software for typing letters to create words, supported with images because $\mathrm{m}_{\mathrm{it}}$ was not related to technology. The reasons for not including guidelines for using worksheets that offer opportunities to practice distinguishing sounds in speech varied highly, were the same reasons for not including attention to making and using vocabulary flashcards with words and images. Both sets of reasons mentioned that these activities were ${ }^{\mathrm{m}}$ not necessarily ICT-specific, and questioned the ${ }^{1}$ value of the medium for the goal stated.

\section{Discussion}

The results of the Delphi study show the respondent expert consensus on the need for the pre-service curriculum to address electronic books and educative television programs; instructions for working with software and specific goals; and forms of interaction and integration of computer activities in (language) teaching. The results also show respondent expert consensus on potentially relevant items that are not needed in the pre-service curriculum, specifically: educative games, interactive white boards, and printers; and guidelines for typing, worksheet use, or vocabulary flashcards. Potential limitations of this study that bear mentioning are: contextual and cultural biases, the relevance of the findings on specific applications in non-Dutch speaking contexts, and respondent attrition.

The conservative nature of respondent expert opinions might be considered in light of existing worries about using technologies with young children at all. Some have argued that embracing them risks promoting a sedentary lifestyle and posing health hazards (Cordes \& Miller, 2000) and we have also been concerned about technologies usurping time for other developmentally appropriate activities such as making music, resolving disputes, engaging in dramatic play, or being outdoors. Such concerns seems warranted as recent studies confirm that parents do not view the technologisation of childhood as a threat (Plowman, McPake, \& Stephen, 2010) even through home media use among young children is on the rise (Vandewater, et al., 2007) and research has found that young children who use home computers a lot spend much less time on sports and outdoor activities and have substantially heavier body mass indices than children who do not use home computers (Attewell, Battle, \& Suazo-Garcia, 2003). Given these developments, it seems important - now more than ever - to educate critical teachers who will use technology when the added value is clear and compelling, bearing in mind that today's children are not at risk of too little screen time. The need for educators and caregivers to adopt a discriminatory stance toward technology use with young children is gaining momentum among policy makers (e.g., Daugherty, Dossani, Johnson, \& Wright, 2014), but research and social campaigns are needed to help early childhood educators identify and use technologies appropriately, intentionally, and productively into early childhood education settings. 


\section{Conclusion}

The present study makes a modest but clear contribution toward articulating the TCK, PCK and TPCK believed to be important for pre-service teachers. In terms of TCK for early literacy, pre-service curricula should devote explicit attention to developing the ability to identify applications and/or hardware that align with the curriculum and are adequate pedagogical tools for achieving the intended learning goals. Specific experience in selecting electronic books and educative television programs is desirable. Because today's pre-service teachers are considered computer literate, practice with common hardware (printers, white boards) is not essential. But for less common applications and/or hardware, pre-service teachers should be taught the crucial importance of learning about how to use the software effectively (and to select resources that articulate clearly what effective use looks like). To support pre-service teachers in their development of PCK for early literacy, attention should be given to the pedagogical opportunities afforded by specific resources and their features. In particular, pre-service teachers should be given opportunities to develop their abilities to identify the learning goals, added-value, evidence-base, and theory behind technology-rich learning resources. To develop TPCK for early literacy, pre-service teachers should be sensitised to the affordances of various forms of interaction (small circle, pairs, teacher-child, small groups) that are possible with specific technologies. But most of all, they should practice well-considered integration of technology in language teaching, with attention to curriculum alignment, thematic alignment, and interaction forms that optimally meet differentiated learning goals. For example, pre-service teachers should be able to describe and justify the selection and use of specific technologies to achieve the Dutch national interim targets for early literacy in classrooms with diverse learners. The findings stress the importance of considering technological possibilities in light of developmentally appropriate practices and specific learning goals.

\section{Acknowledgements}

The authors wish to express their gratitude to the experts who participated in the study. Further, we thank the Dutch National Research Foundation - Program for Educational Research (NWO-PROO) that funded the present study (project number 411-07-219). Finally, we express our appreciation to Nelleke Belo for her assistance on the first two rounds of data collection reported in this article.

\section{References}

Attewell, P., Battle, J., \& Suazo-Garcia, B. (2003). Computers and young children: Social benefit or social problem?. Social Forces, 82(1), 277-296.

Belo, N., McKenney, S., Voogt, J., \& Bradley, B. (2016). Teacher knowledge for using technology to foster early literacy: A literature review Computers in Human Behavior. 60, 372-383. https://doi.org/10.1016/j.chb.2016.02.053

Cassady, J. C., \& Smith, L. L. (2003). The impact of a reading-focused integrated learning system on phonological awareness in kindergarten. Journal of Literacy Research, 35(4), 947-964.

Cordes, C., \& Miller, E. (2000). Fool's gold: A critical look at computers in childhood. College Park, MD: Alliance for Childhood.

Daugherty, L., Dossani, R., Johnson, E. \& Wright, C. (2014). Moving beyond screen time: Redefining developmentally appropriate technology use in early childhood education. Santa Monica, CA: The Rand Corporation.

Diamond, I. R., Grant, R. C., Feldman, B. M., Pencharz, P. B., Ling, S. C., Moore, A. M., \& Wales, P. W. (2014). Defining consensus: a systematic review recommends methodologic criteria for reporting of Delphi studies. Journal of Clinical Epidemiology, 67(4), 401-409. https://doi.org/10.1016/j.jclinepi.2013.12.002

Enochssen, A., \& Rizza, C. (2009). ICT in initial teacher training: Research review. Paris: OECD Education Working Papers, No. 38, 41p. https://doi.org/10.1787/220502872611

Hartley, K., \& Bendixen, L. D. (2001). Educational research in the Internet age: Examining the role of individual characteristics. Educational Researcher, 30(9), 22-26.

Hasson, F., Keeney, S., \& McKenna, H. (2000). Research guidelines for the Delphi survey technique. Journal of Advanced Nursing, 32(4), 1008-1015.

Haussler, P., Frey, K., Hoffman, L., Rost, J., \& Spada, H. (1980). Education in physics for today and tomorrow. Kiel: IPN. 
Hsu, C., \& Sandford, B. (2007). The Delphi technique: Making sense of consensus. Practical Assessment, Research \& Evaluation, 12(10), 1-8. https://doi.org/10.1046/j.1365-2648.2000.t01-1-01567.x

Koehler, M. J., \& Mishra, P. (2009). What is technological pedagogical content knowledge? Contemporary Issues in Technology and Teacher Education, 9(1), 60-70.

Koh, J. H. L., Chai, C. S., \& Tay, L. Y. (2014). TPACK-in-action: Unpacking the contextual influences of teachers' construction of technological pedagogical content knowledge (TPACK). Computers \& Education, 78, 20-29. https://doi.org/10.1016/j.compedu.2014.04.022

Lankshear, C., \& Knoebel, M. (2003). New technologies in early childhood literacy research: A review of research. Journal of Early Childhood Literacy, 3(1), 59-82. https://doi.org/10.1177/14687984030031003

McKenney, S., \& Voogt, J. (2009). Designing technology for emergent literacy: The PictoPal initiative. Computers \& Education, 52(4), 719-729. https://doi.org/10.1016/j.compedu.2008.11.013

National Association for Education of Young Children (1996). Technology and young children: Ages 3-8 [Position statement]. Retrieved from http://www.naeyc.org/about/positions/PSTECH98.asp

Osborne, J., Collins, S., Ratcliffe, M., Millar, R., \& Duschl, R. (2003). What "ideas-about-science" should be taught in school science? A Delphi study of the expert community. Journal of Research in Science Teaching, 40(7), 692-720. https://doi.org/10.1002/tea.10105

Pelletier, J., Reeve, R., \& Haylewood, C. (2006). Young children's knowledge building and literacy development through Knowledge Forum. Early Education and Development, 17(3), 323-346. https://dx.doi.org/10.1207/s15566935eed1703_2

Plowman, L., McPake, J., \& Stephen, C. (2010). The technologisation of childhood? Young children and technology in the home. Children \& Society, 24(1), 63-74. https://doi.org/10.1111/j.10990860.2008.00180.x

Robinson, L., Johanson, J., Schneider, C., \& Hutinger, P. (2006). Final Report: Interactive Technology Literacy Curriculum Online (ITLC Online). Center for Best Practices in Early Childhood Education.

Segers, E., \& Verhoeven, L. (2002). Multimedia support of early literacy learning. Computers in Education, 39(3), 207-221. https://dx.doi.org/10.1016/S0360-1315(02)00034-9

Shaikh, Z., \& Khoja, S. (2014). Personal learning environments and university teacher roles explored using Delphi. Australasian Journal of Educational Technology, 30(2), 202-226. https://doi.org/10.14742/ajet.324

Smith, K. S., \& Simpson, R. D. (1995). Validating teacher competencies for faculty members in higher education: A national study using Delphi study methods. Innovative Higher Education, 19(3), 223234. https://doi.org/10.1007/BF01191221

So, H., \& Bonk, C. (2010). Examining the roles of blended learning approaches in computer-supported collaborative learning (CSCL) environments: A Delphi study. Educational Technology \& Society, 13(3), 189-200.

Takacs, Z. K., Swart, E. K., \& Bus, A. G. (2015). Benefits and pitfalls of interactive features un technology-enhanced storybooks. A meta-analysis. Review of Educational Research, 85(4), 698-739. https://doi.org/10.3102/0034654314566989

Tondeur, J., Aesaert, K., Pynoo, B., Braak, J., Fraeyman, N., \& Erstad, O. (2015). Developing a validated instrument to measure preservice teachers' ICT competencies: Meeting the demands of the 21st century. British Journal of Educational Technology. https://doi.org/10.1111/bjet.12380

Tondeur, J., Pareja Roblin, N., Braak, J. van, Fisser, P., \& Voogt, J. (2013). Technological pedagogical content knowledge in teacher education: In search of a new curriculum. Educational Studies, 39(2), 239-243. https://doi.org/10.1080/03055698.2012.713548

Tondeur, J., van Braak, J. Guoyuan, S. Voogt, J., \& Fisser, P.\& Ottenbreitt-Leftwich, AS. (2012). Preparing student teachers to integrate ICT in classroom practice: a synthesis of qualitative evidence. Computers \& Education, 59(1), 134-144. https://doi.org/10.1016/j.compedu.2011.10.009

Vandewater, E. A., Rideout, V. J., Wartella, E. A., Huang, X., Lee, J. H., \& Shim, M. S. (2007). Digital childhood: Electronic media and technology use among infants, toddlers, and preschoolers. Pediatrics, 119(5), e1006-e1015.

Van Scoter, J. (2008). The Potential of IT to Foster Literacy Development in Kindergarten. In J. V. Knezek (Ed.), International Handbook of Information Technology in Education (pp. 149-161). London: Springer.

Verhallen, M., Bus, A., \& de Jong, M. (2006). The promise of multimedia stories for kindergarten children at-risk. Journal of Educational Psychology, 98, 410-419.

Volman, M. (2005). A variety of roles for a new type of teacher: Educational technology and the teaching profession. Teaching and Teacher Education, 21(1), 15-31. https://doi.org/10.1016/j.tate.2004.11.003 
Voogt, J., Fisser, P., Pareja Roblin, N., Tondeur, J., \& Van Braak, J. (2012). Technological pedagogical content knowledge - A review of the literature. Journal of Computer Assisted Learning, https://doi.org/10.1111/j.1365-2729.2012.00487.x

Voogt, J. \& McKenney, S. (2016). TPACK in teacher education: Are we preparing teachers to use technology for early literacy? Technology, Pedagogy and Education. https://doi.org/10.1080/1475939X.2016.1174730ht

Wang, L., Ertmer, P. A., \& Newby, T. J. (2004). Increasing preservice teachers' self-efficacy beliefs for technology integration. Journal of Research on Technology in Education, 36(3), 231-250. https://doi.org/10.1080/15391523.2004.10782414

Webb, M., \& Cox, M. (2004). A review of pedagogy related to information and communications technology. Technology, Pedagogy and Education, 13(3), 235-286. https://doi.org/10.1080/14759390400200183

Wright, V. H., \& Wilson, E. K. (2005). From preservice to inservice teaching: A study of technology integration. Journal of Computing in Teacher Education, 22(2), 49-55.

Corresponding author: Susan McKenney, susan.mckenney@utwente.nl

Australasian Journal of Educational Technology (c) 2017.

Please cite as: McKenney, S., \& Voogt, J. (2017). Expert views on TPACK for early literacy: Priorities for teacher education. Australasian Journal of Educational Technology, 33(5), 1-14.

https://doi.org/10.14742/ajet.2502 